DOI: 10.22591/magyurol.2017.3.huttla.113

\title{
High flow priapizmus két esete - diagnosztika és kezelés
}

\author{
Hüttl András Béla dr. , Kopa Zsolt dr. , Dósa Edit dr.', \\ Hüttl Kálmán dr.2, Nyirády Péter dr. ${ }^{1}$, Riesz Péter dr. ${ }^{1}$
}

'Semmelweis Egyetem, Urológiai Klinika, Budapest (igazgató: Nyirády Péter dr.)

${ }^{2}$ Semmelweis Egyetem, Városmajori Szív- és Érgyógyászati Klinika, Budapest (igazgató: Merkely Béla dr.)

Levelezési cím:
Dr. Hüttl András
Semmelweis Egyetem, Urológiai
Klinika
1082 Budapest, Üllői út 78/b
e-mail: andrashutt|@gmail.com

\begin{abstract}
ÖSSZEFOGLALÁS
Bevezető: A high flow priapizmus ritka betegség Magyarországon. Fontos a helyes diagnózis felállítása, és a korszerű kezelés kiválasztása.

Esetismertetés: A Semmelweis Egyetemen ellátott két high flow priapizmussal kezelt beteg esetét mutatjuk be és ismertetjük az ide vonatkozó, aktuális Európai irányelveket.

Következtetések: Annak érdekében, hogy megfelelő diagnózishoz jussunk, illetve a betegek a legkorszerúbb ellátást kapják fontos, hogy a high flow priapizmus ellátása centrumokban történjen.
\end{abstract}

\section{KULCSSZAVAK}

HIGH FLOW PRIAPIZMUS, EMBOLIZÁCIÓ, SÉRÜLÉS, PARANEOPLÁZIA

\section{Bevezető}

Priapizmusnak nevezzük azt a kóros állapotot, amikor a hímveszsző legalább 4 órán keresztül vagy annál hosszabb ideig, ingerlés nélkül, erektilis állapotban van (1). A szakirodalom a priapizmust három csoportra osztja: vénás (low flow), artériás (high flow), valamint rekurrens vagy intermittáló. Az esetek 95\%-a vénás típusba tartozik, az artériás priapizmus ritka kórkép, hazánkban, ellátásában nincsen kialakult gyakorlat, sem adatok a kezelt betegek utánkövetésével kapcsolatban. 2015-ben a Semmelweis Egyetem Urológiai Klinikáján két esetben (továbbiakban „A" illetve " $B$ " beteg) diagnosztizáltunk high flow priapizmust és a Városmajori Szív- és Érgyógyászati Klinika intervenciós radiológiai részlegének segítségével láttuk el a betegeket.

\section{Esetismertetés}

"A" beteg, 35 éves férfi, esetében a kórok kerékpározás közben elszenvedett gáttáji sérülés volt. "B" beteg, középkorú férfi, vesetumor miatt onkológiai ke-

\section{Priapism - case report of two high flow priapism patients}

\section{SUMMARY}

Background: High flow priapism is a relatively rare disease in Central Europe. Making the correct diagnosis and the management of high flow priapism is not well established yet in Hungary. Case report: In this paper we present the diagnosis and the treatment of two cases of high flow priapism that were treated at Semmelweis University Hospitals (Budapest). We also review the related European Urology Guidelines (EAU).

Conclusion: We conclude that the treatment of high flow priapism needs to be centralized in Hungary in order to make the right diagnosis and to be able to choose the best treatment for the given patient.

\section{KEYWORDS}

HIGH FLOW PRIAPISM, EMBOLIZATION, TRAUMA, PARANEOPLASTIC SYNDROME

zelés alatt áll. Esetében a high flow priapizmus kialakulásának hátterében nem találtunk egyértelmü okot. A beteg gáttáji traumát nem szenvedett el, vizsgálataink során a hímvesszőben malignus elváltozást nem találtunk. Tekintettel elörehaladott daganatos betegségére felmerül, hogy az ő esetében a priapizmus, egy paraneopláziás jelenség volt, bár ezt a kórokot csak egy példa tudta megerősíteni a szakirodalomban (2). "A" beteg esetében a gáttáji sérülés felvetette high flow priapizmus lehetöségét. Anamnézise alapján a sérüléstöl számitott 3. napra alakult ki a hímvessző nem szünő merevedése. Ez az állapot, amely a glans-ot is érintette, nem járt fájdalommal, fizikális vizsgálat során iszkémiás jelek, illetve, külsérelmi nyom a hímvessző és a gáttájékon nem mutatkozott. Color Duplex ultrahangvizsgálat során az arteria profunda penisben megtartott keringés ábrázolódott, a hímvessző proximális részén a corpus cavernosumot ellátó kis artéria és a vénás sinusok között turbulens áramlás ábrázolódott. "B" beteg anamnézise alapján a high flow priapizmusnak egyértelmü okát nem találtuk. "A $A$ " esettel össze- 
hasonlítva vizsgálataink során a hímvessző tapintásakor fájdalmat jelzett a beteg, iszkémiára utaló fizikális eltérést nem találtunk. Color Duplex ultrahangvizsgálat a hímvesszőben megtartott keringést és a proximális részén, két helyen is turbulens áramlást mutatott. Vérgáz-analizist egyik beteg esetében sem végeztünk tekintettel arra, hogy a hímvesszőből történő mintavétel fájdalmas, illetve a többi vizsgálat alapján egyértelmü diagnózist tudtunk felállítani. A panaszok mindkét beteg esetében régóta fennálltak, konzervatív terápia (hütés, kompresszió) egyik beteg esetében sem bizonyult hatásosnak, ezért embolizáció mellett döntöttünk. Mindkét embolizációt megelőzően szelektív angiográfia történt a high flow priapizmust okozó léziók igazolására.

"A" betegnél első alkalommal a lézió ultrahangvezérelt direkt rászúrása, majd trombin injektálása történt (3). A beavatkozás átmenetileg mérsékelte a tüneteket, de nem adott végleges megoldást, igy szuperszelektív embolizációt végeztünk arteria femoralison keresztül történő behatolásból. Az embolizáció mikrokatéteren keresztül, finomra reszelt, felszivódó spongosztán szemcsékkel történt (1-2. ábra). A priapizmus oldódása a beavatkozás után 2 órával már látható volt.

"B" esetben, ugyanazt a módszert alkalmazva, mint "A" betegnél, szuperszelektív embolizációt végeztünk. A beavatkozás hatására a tünetek csökkentek, de nem szüntek meg teljesen, így a beavatkozást megismételtük, amely végül kielégítő eredményt adott.

Akut szövődmény a beavatkozások után nem volt. "A" beteg a beavatkozást követően másfél hónappal középsúlyos merevedési panaszokról számolt be. Gyógyszeres terápiát, avanafil 50 mg-ot, inditottunk el, amelynek hatására a merevedése jelentősen javult. A megbeszélt kontrollvizsgálatra a beteg nem jelentkezett. A beavatkozás után 9 hónappal kereste fel intézetünket, elmondása alapján gyógyszeres terápia nélkül 80-90\%-os merevedést tudott elérni, hajnali merevedése rendszeresen van.

" $B$ " beteg esetében a beavatkozás után 4 nappal a glans penisen kb. 1,5 cm-es gangrénás elváltozás jelent meg, amely ismert szövődmény az embolizációt követően (4). Ennek oka az, hogy az embolizáció során, még úgy is, hogy mikrokatéterrel történik a beavatkozás, olyan erekbe is juthat embolizáló anyag (a mi esetünkben finomra reszelt spongosztán szem(se), amely ép szöveteket lát el. Ezekben a szövetekben iszkémiás nekrózis alakulhat ki. Az elváltozás tisztán tartása és hámosítást serkentő krémek hatására egy hónapon belül meggyógyult. A betegnek a beavatkozást megelőzően már volt erektilis diszfunkciója, igy a beavatkozás hatására annak számottevő változásáról nem tudunk nyilatkozni. A beteg jelenleg onkológiai kezelés alatt áll metasztatikus vesetumor miatt.

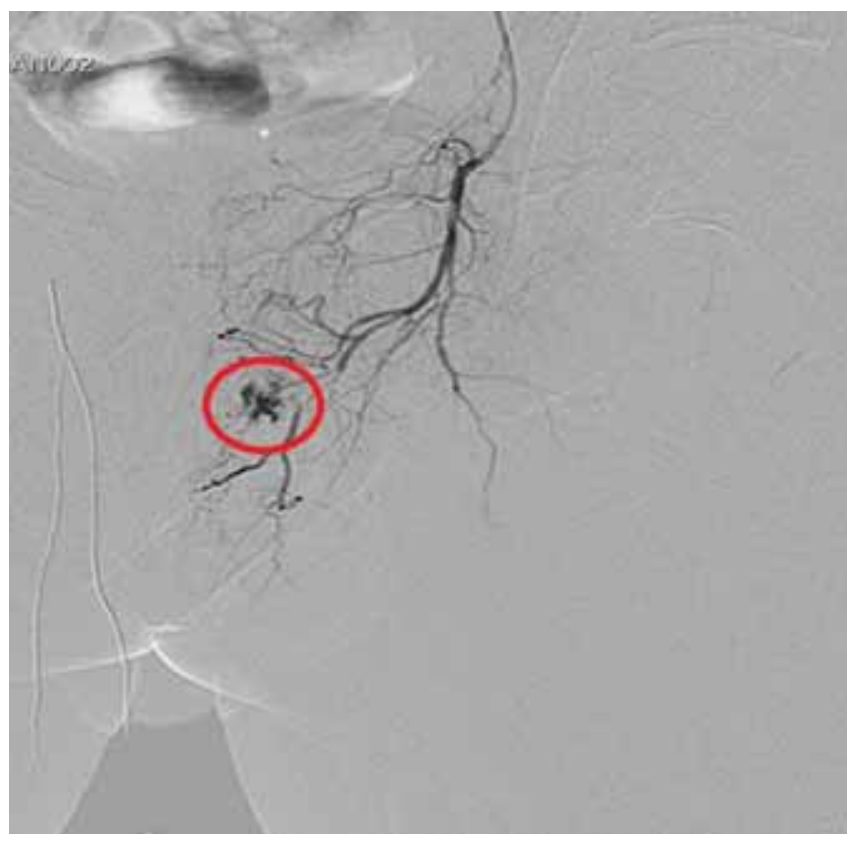

1. ÁBRA: KONTRASZTANYAG-KILÉPÉS ANGIOGRÁFIÁS VIZSGÁLAT SORÁN

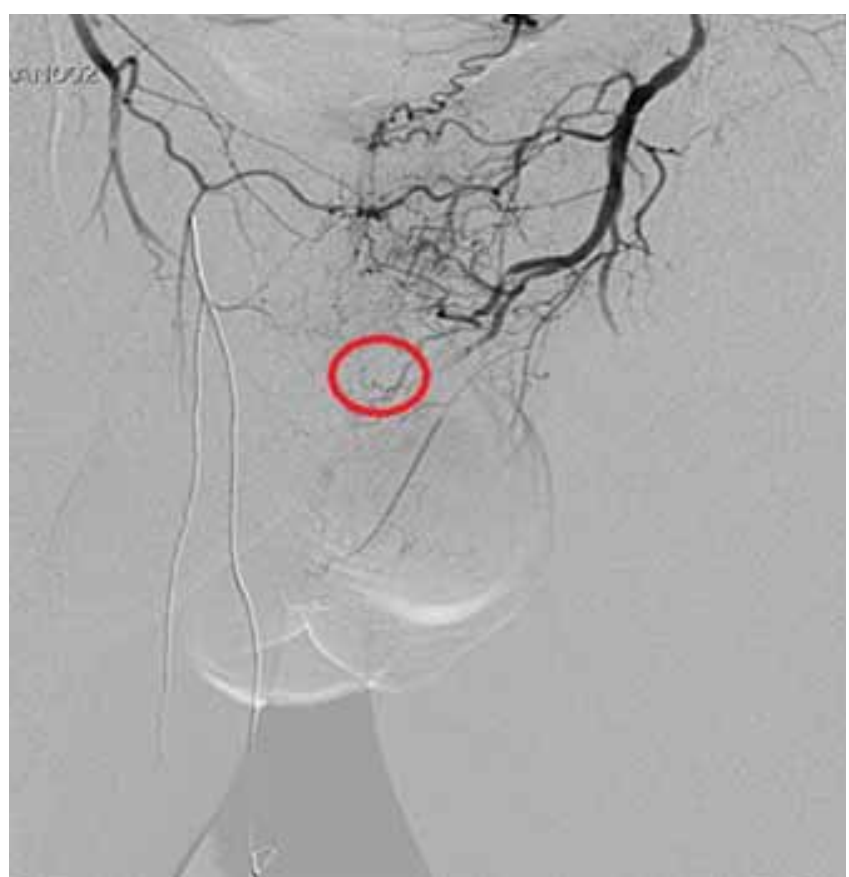

2. ÁBRA: A KONTRASZTANYAG-KILÉPÉS MEGSZÜNT AZ EMBOLIZÁCIÓ UTÁN

\section{Megbeszélés}

Általánosságban elmondható, hogy high flow priapizmus esetén az elsődleges etiológiai tényező a hímvessző vagy a gáttájék tompa sérülése. A sérülés következtében az arteria profunda penis vagy annak valamelyik ága lacerálódik. A sérülés helyén magas áramlású fisztula keletkezik az artéria és a 
corpus cavernosum között. A laceráció helyén lévő turbulens áramlás az endothelium nitrogén-monoxid termelésének fokozódását okozza, ezáltal fenntartja a priapizmus állapotát (5). A low flow priapizmus kialakulásában szerepet játszó gyakoribb tényezők: sarlósejtes anémia, intracavernosus injekció, áttétes daganat a hímvesszőben, gerinc trauma, urethrotomia interna (6-10).

A helyes diagnózis felállítása, a low flow és a high flow priapizmus elkülönítése rendkívül fontos. A low flow priapizmus más ellátást igényel és a lehető legrövidebb időn belül. Fontos a betegek kórelőzményének részletes kikérdezése (korábbi betegségek, trauma, panaszok kezdete, kísérő fájdalom) (Grade B). A trauma ideje és a tünetek megjelenése között akár több nap is eltelhet. High flow priapizmus esetén fizikális vizsgálat során elsősorban a következő kóros eltéréseket találjuk: ingerlés nélkül, hosszú ideje tartó, általában nem teljes mértékú, gyakran a glans penist is érintő merevedés, amely általában fájdalmatlan. Néha a hímvessző lüktetése észlelhető iszkémia jele nélkül. Keresni kell a traumára utaló külsérelmi nyomokat a gáttájon és a hímvesszőn (Grade B) (1. táblázat).

\section{Képalkotó vizsgálatok}

A hímvessző és a gáttájék Color Duplex ultrahangvizsgálata javasolt. A sérülés helyén a corpus cavernosum artériás ellátása és a vénás sinusok között turbulens áramlás figyelhető meg. Az arteria profunda penisben általában jó keringés észlelhető.

\section{TÁBLÁZAT: A HIGH FLOW ÉS A LOW FLOW PRIAPIZMUS DIFFERENCIÁLDIAGNOSZTIKÁJA (EAU GUIDELINE 2016)}

\begin{tabular}{|c|c|c|}
\hline & $\begin{array}{l}\text { Low flow } \\
\text { priapizmus }\end{array}$ & $\begin{array}{l}\text { High flow } \\
\text { priapizmus }\end{array}$ \\
\hline $\begin{array}{l}\text { A hímvessző } \\
\text { teljes merevedése }\end{array}$ & általában & ritkán \\
\hline $\begin{array}{l}\text { Hímvessző } \\
\text { fájdalom }\end{array}$ & általában & ritkán \\
\hline $\begin{array}{l}\text { Abnormális } \\
\text { vérgázértékek }\end{array}$ & általában & ritkán \\
\hline $\begin{array}{l}\text { Hematológiai } \\
\text { betegség }\end{array}$ & általában & ritkán \\
\hline $\begin{array}{l}\text { Intracorporális } \\
\text { injekció }\end{array}$ & előfordul & előfordul \\
\hline $\begin{array}{l}\text { Gáttáji/hímvessző- } \\
\text { trauma }\end{array}$ & ritkán & általában \\
\hline
\end{tabular}

Szuper szelektív angiográfián az érpályából kontrasztanyag kilépést, kontrasztanyag- „tócsát” tapasztalhatunk. Angiográfiás vizsgálat abban az esetben javasolt, amennyiben intervenciót is tervezünk (Grade B).

\section{Laboratóriumi vizsgálatok}

Teljes vérkép, véralvadási paraméterek. A high flow priapizmus esetén a hímvesszőből vett vérgáz-analízis jól oxigenizált artériás vérnek megfelelö értékeket ad: $\mathrm{pO}_{2}>90 \mathrm{Hgmm}, \mathrm{CO}_{2}$ $<40$ Hgmm, pH=7,4. A high flow priapizmusnál hímvesszőből vett vér az oxigenizáltságnak megfelelően élénkpiros színú szemben a low flow priapizmusnál tapasztalható sötétebb árnyalatú vörös színnel (Grade B).

\section{Terápia}

A high flow priapizmus szemben az iszkémiás priapizmussal nem igényel azonnali ellátást, tekintettel arra, hogy a szövetek oxigenizációja megfelelő. A konzervatív terápia a gáti régió hútését és kompresszióját jelenti, amely az esetek többségében nem vezet gyógyuláshoz, ennek ellenére a spontán remisszió lehetősége is fennáll (11). A legtöbb esetben végleges megoldás a sérült artéria szuperszelektív embolizációjától várható (12-15). Betegeink esetében az érpályába történő behatolás az arteria femoralis szúrásával, Seldinger-technika szerint történt. A katétert fel kell vezetni az arteria pudenda internába, majd érfestés során azonosítani az érsérülést. Az embolizációt gyakran mikrokatéterrel végzik az érintett erek kis átmérője miatt. A szakirodalom alapján embolizációhoz használt anyag lehet felszívódó vagy nem felszívódó. A nem felszívódó anyagok magukban rejtik a veszélyt, hogy amenynyiben nemcsak az érintett lézió lett embolizálva, hanem egyéb egészséges szöveteket ellátó erek is, úgy ezekben az ép szövetekben maradandó károsodást okozunk. Sajnos az embolizáció szelektivitása nem mindig garantált. Eredménytelenség esetén a beavatkozás megismételhető. A beavatkozás után körülbelül 20\%-ban alakul ki erektilis diszfunkció (16). Egyéb lehetséges szövődmények az artéria behatolási pontjánál keletkező haematoma, az intervenció során fellépő tromboembóliás szövődmények, hímvesszőn kialakuló gangréna, gluteális régió iszkémiája, cavernositis és perineális abscessus (17).

Hosszú távú követése szempontjából objektívabb információt nyerhettünk volna betegeinktől, amennyiben a merevedést kérdőívek segítségével mérjük fel. Ennek bevezetését tervezzük a jövőben.

\section{Következtetések}

A high flow priapizmus ritka kórkép, amelynek diagnosztizálása, illetve kezelése speciális szakértelmet igényel. Fontos, hogy az ellátás centrumokban történjen intervenciós radiológusok együttmúködésével. A jövőben fontos a betegek hoszszú távú követése, hogy a kezelésünk hatékonyságát még jobban tudjuk ellenőrizni. 


\section{Irodalom}

1. Salonia I, Eardley F, Giuliano I, Moncada K. Hatzimouratidis, EAU Guideline. Guidelines on Priapism 2016.

2. Greschner M, Krautschick A, Alken P. High-flow priapism leading to the diagnosis of lung cancer. Urol Int 1998; 60(2): 126-7. https://doi.org/10.1159/000030227

3. Kiss A, Polovitzer M, Merksz M, Kardos A, Schaffer P, Apor A, Hüttl $K$. Treatment of posttraumatic high-flow priapism in 8-year-old boy with percutaneous ultrasound-guided thrombin injection. Urology 2007 Apr; 69(4): 779e7-9. https://doi.org/10.1016/j.urology. 2007.02.012

4. Sandock DS, et al. Perineal abscess after embolization for high-flow priapism. Urology 1996; 48(2): 308-11. https://doi.org/10.1016/s00904295(96)00176-8

5. Witt MA, Goldstein I, Saenz de Tejada I, et al. Traumatic laceration of intracavernosal arteries: the pathophysiology of nonischemic, high flow, arterial priapism. J Urol 1990 Jan; 143(1): 129-32.

6. Dubocq FM, Tefilli MV, Grignon DJ, et al. High flow malignant priapism with isolated metastasis to the corpora cavernosa. Urology 1998 Feb; 51(2): 324-6. https://doi.org/10.1016/s00904295(97)00607-9

7. Inamoto $T$, Azuma $H$, Iwamoto $Y$, et al. A rare case of penile metastasis of testicular cancer presented with priapism. Hinyokika Kiyo 2005 Sep; 51(9): 639-42.

8. Todd NV. Priapism in acute spinal cord injury. Spinal Cord 2011 Oct; 49(10): 1033-5. https://doi.org/10.1038/sc.2011.57

9. Lutz A, Lacour S, Hellstrom W. Conversion of low-flow to high-flow priapism: a case report and review (CME). J Sex Med 2012 Apr; 9(4):
951-4. quiz 5. https://doi.org/10.1111/j.1743-6109.2012.02692.x

10. McMahon CG. High flow priapism due to an arterial-lacunar fistula complicating initial veno-occlusive priapism. Int J Impot Res 2002 Jun; 14(3): 195-6. https://doi.org/10.1038/sj.iji.3900828

11. Ilkay AK, Levine LA. Conservative management of high-flow priapism. Urology $1995 \mathrm{Sep} ; 46(3):$ 419-24. https://doi.org/10.1016/ s0090-4295(99)80235-0

12. Karagiannis AA, Sopilidis OT, Brountzos E, et al. High flow priapism secondary to internal urethrotomy treated with embolization. $J$ Urol 2004 Apr; 171(4): 1631-2. [No abstract available] https://doi.org/ 0.1097/01.ju.0000116287.03211.8d

13. Burnett AL, Bivalacqua TJ. Priapism: new concepts in medical and surgical management. Urol Clin North Am 2011 May; 38(2): 185-94. https://doi.org/10.1016/j.ucl.2011.02.005

14. Kim KR, Shin JH, Song HY, et al. Treatment of high-flow priapism with super selective transcatheter embolization in 27 patients: a multicenter study. J Vasc Interv Radiol 2007 Oct; 18(10): 1222-6.

15. Rózsahegyi J, Kopa Zs, Major L, Szabó F, Laki A, Papp Gy, Kovács G. „High-flow" priapismus sikeres megoldása szuperszelektív embolizációval. Magyar Urológia 2001; 13(3): 279-284.

16. Savoca G, et al. Sexual function after highly selective embolization of cavernous artery in patients with high flow priapism: long-term followup. J Urol 2004; 172(2): 644-7. https://doi.org/10.1097/01.ju. 0000132494.44596 .33

17. Broderick GA, et al. Priapism: pathogenesis, epidemiology, and management. J Sex Med 2010; 7(1 Pt 2): 476-500. https://doi.org/ 10.1111/j.1743-6109.2009.01625.x 